\title{
Ocjena proizvodnog prostora Knina za uzgoj masline
}

\author{
Evaluation of production area of Knin for olive growing
}

D. Dujmović, M. Šuste, M. Duvančić, F. Strikić

\section{SAŽETAK}

U posljednjih dvadesetak godina zahvaljujući klimatskim promjenama u svijetu i kod nas postoji pozitivan trend širenja masline. Kultura uzgoja masline uglavnom se širi u područja netipična za uzgoj ove vrste. Netipični maslinarski prostor je područje Unutrašnjosti Dalmacije koji obuhvaća područja gradova Obrovac, Benkovac, Knin, Drniš, Sinj, Imotski i Vrgorac. Tako je u zadnja dva desetljeća u području Unutrašnjosti Dalmacije posađeno nekoliko tisuća stabala masline. Najčešći razlog sadnje su navodne „klimatske promjene“ koje su dovele po riječima proizvođača do mogućnosti uzgoja masline i ovom području. Sadnja se uglavnom odvija bez konzultacija sa strukom i znanosti te bez kvalitetne analize proizvodnog prostora za uzgoja masline. U ovom radu analizirane su klimatske i pedološke prilike u području grada Knina kako bi kvalitetno ocijenili prostor za uzgoj masline. Glavni ograničavajući čimbenik uzgoja masline u ovom području jesu klimatske prilike. U analizi klimatskih prilika koristili smo se metodom za ocjenu klimatskih prilika za uzgoj masline po Briccoliu (1925.) modificiranoj prema Miljkoviću (1984.). Od mogućih 60 bodova za odnos temperature i oborina Knin ima 40,5. Kada se oduzmu negativni bodovi za klimu dobije se rezultat od -11.5 bodova. Radi ove činjenice područje Knina zaslužuje negativnu ocjenu za uzgoj maslina s obzirom na klimu što ponajviše može zahvaliti niskim temperaturama. Iz ovog možemo zaključiti kako analizirano područje nije pogodno za komercijalni uzgoj masline, a istovremeno postoji mogućnost uzgoja na pojedinim mikrolokacijama koje treba pažljivo analizirati.

Ključne riječi: maslina, ocjena proizvodnog prostora, klimatske prilike, područje uzgoja

\begin{abstract}
In the last twenty years due to climate change in the world and in our country, there is a positive trend of the spreading of olive. Culture of growing olives mainly spreads in atypical growing areas for this species. Atypical olive growing area is the area of the Dalmatian hinterland, which includes the cities of Obrovac, Benkovac, Knin, Drniš, Sinj, Imotski and Vrgorac. In the last two decades in the area of the Dalmatian hinterland thousands of olive trees have been planted. The most common reason for
\end{abstract}


planting is the alleged "climate change" that led, in the words of the producers, to the possibility of growing olives is this region. Planting is mostly done without consultation of profession and science, and without a thorough analysis of the production area for growing olives. This paper analyzes the climate and soil conditions in the area of Knin city, to assess quality space for growing olives. The main limiting factor for growing olive trees in this area are the climatic conditions. In the analysis of climatic conditions we used method for assessing climatic conditions for growing olives according Briccoli (1925.) modified to Miljković (1984.). Out of a possible 60 points for the relationship of temperature and precipitation, Knin has 40.5. When deducting penalties for climate, yields a result of -11.5 points. Because of this fact the Knin area deserves a negative assessment of olive cultivation due to the climate that largely owes to low temperatures. From this we can conclude that the analyzed area is not suitable for commercial cultivation of olive trees, and at the same time there is the possibility of growing in some locations that need to be carefully analyzed.

Keywords: olive, evaluation of production space, climate, farming area

\section{UVOD}

Maslina (Olea europaea L.) se uzgaja umjerenog klimatskog pojasa, a 98,8\% proizvodnje odvija se na Mediteranu. Osim u području Mediterana maslina se uzgaja u Čileu, Argentini, Južnoj Africi, SAD-u, Australiji, Kini, Japanu te u području Crnog mora. Prema podacima IOC (International Olive Council, Madrid, 2016.) maslina se u svijetu uzgaja na površini od 11.382.383 ha. U Hrvatskoj se maslina uzgaja u uskom obalnom i otočnom prostoru te na pojedinim mikrolokacijama u Unutrašnjosti Dalmacije. Ukupna površina pod maslinom je 19.100 ha (IOC, 2016), a na ovoj površini se uzgaja oko 6.1 milijuna stabala (Strikić et all., 2012.). Cijelo uzgojno područje podijeljeno je u šest podregija uzgoja koje su izdvojene na osnovu pedoloških i klimatskih karakteristika. U uzgoju se nalazi 75 sorta od čega 31 domaća i 44 uvezene sorte (Gugić, 2007.).

Područje Knina uvršteno je u Jadransku poljoprivrenu regiju, J-2 Sjeverno jadranska podregija (Bašić, 2004.), a u maslinarskim podrajonima područje je svrstano u VIII podregiju Dalmatinska zagora (Zec, 1951.), a prema Miljkoviću (1984.) područje Knina svrstano je u IX podrajon Dalmatinska zagora. O zastupljenosti masline u području Knina govore mnogi dokumenti, a uvijek se 
govori o problemu klimatskih čimbenika koji onemogućavaju komercijalni uzgoj masline. Osim agroekoloških čimbenika komercijalni uzgoj masline na ovom području ograničavan je i zakonskim propisima. Tako je poznat Grimanijev zakon ili terminacija (1755.) koji je središnji dokument koji regulira posjedovne $\mathrm{i}$ društvene odnose $\mathrm{u}$ agrarnoj politici na prostoru Unutrašnjosti Dalmacije od Zrmanje do Neretve). Ove zakone je odobrio Mletački senat, a to je pokušaj unaprijeđenja poljoprivredne proizvodnje na ovom području. Propisao je koliko stabala kestena, oraha, šljive, maraske, duda ili masline (ovisno o klimi i vrsti tla) treba posaditi na zemlju dobivenoj od države, koliko svaka obitelj mora držati košnica i koje povrće mora sijati u vrtu (kupus, crveni i bijeli luk, ljutiku). Cilj nije bio poticati komercijalnu proizvodnju, nego stvoriti uvjete za samodostatnu poljoprivrednu proizvodnju obiteljskih poljoprivrednih gospodarstava, a koje su oni do tada kupovali na tržištu. Maslina se uzgaja sporadično ili kao pojedinačna stabla s nešto većim intenzitetom u području Benkovca, Ostrovice, Roškog slapa, Miljevaca i Knina. Nadalje, zbog jakih udara bure i šteta od koze i ovce maslina se manje uzgaja u području Sinja ( Micheli Vitturi, 1788.). Na početku druge polovica 19. stoljeća voćarstvo i maslinarstvo na kninskom području nije bilo na osobitoj razini. Tomu je razlog bila činjenica da klimatske prilike nisu bile pogodne za uzgoj masline. Spominje se da se u cijelom kotaru dobivalo samo jedno barilo (oko 150 1) maslinova ulja (Peričić, 1998/99.).

Tijekom dvadesetog stoljeća, zahvaljujući spoznajama o klimatskim promjenama, maslina se počela širiti i u područje Knina. Ovo širenje nema veći ekonomski značaj ali je maslina sve više prisutna u području Knina, Vrbnika, Kistanja, Biskupije i drugim mjestima u neposrednoj blizini grada. Kako bi pomogli sadašnjim i budućim maslinarima ovog područja obavili smo vrednovanje agroekoloških uvjeta za uzgoj masline u području Knina.

\section{MATERIJAL I METODE RADA}

Prostor i pedološke prilike Knina

Područje grada Knina nalazi se u unutrašnjosti Dalmacije na 47 km zračne linije od morske obale. Geografske koordinate samog grada Knina su $44^{\circ} 02^{\prime} 45^{\prime \prime} \mathrm{N}$ i $16^{\circ} 12^{\prime} 30^{\prime \prime} \mathrm{E}$. Prostor grada Knina obuhvaća grad Knin te dijelove naselja Kninsko polje, Vrpolje, Kovačići i Potkonje. U orografskom smislu radi se o uglavnom ravnom području ili području s nagibom terena do 5\%., a predstavlja veliko krško polje (Juras, 1957.). U geološkom smislu prostor Knina predstavlja aluvijalni nanosi iz doba Halocena. Nadmorska visina područja grada je 214 metara. Sa sjeverne strane prostor je omeđen 
planinom Dinarom $(1.913 \mathrm{~m})$ dok je s južne strane planinom Prominom $(1.148 \mathrm{~m})$ koja priječi prodor toplih morskih struja u ovaj prostor.

U području su zastupljena četiri tipa tala i to: litogeno-karbonatna (Knin, Vrpolje, Vedro polje, Burnum) i aluvijalna tla (obale Butišnice, Radljevca, Knin) koja zauzimaju najznačajnije mjesto na obradivim površinama te se na njima odvija najveći dio poljoprivredne proizvodnje ovog područja. Pored ova dva tipa tala uglavnom oko naselja nalazimo antropogena tla ta litogeno silikatna tla i močvarna tla u neposrednoj blizini potoka Butižnice i Orašnice (Juras, 1957.). Najveće površine zauzimaju aluvijalna tla s dubinom profila većom od $150 \mathrm{~cm}$. Po teksturnom sastavu ovo su glinasto ilovasta ili ilovasta tla s reakcijom pH 7.10 do pH 8.33, a iz čega možemo zaključiti da se radi o blago alkalnom tlima (Juras, 1957).

Klimatske prilike područja Knina

Za analizu smo koristili osnovne klimatske parametre sa meteorološke postaje Knin za razdoblje 1990.-2010., a srednje mjesečne i godišnje temperature zraka prikazane su u tablici 1.

Tablica 1. Srednje mjesečne i godišnje temperature zraka $\left(C^{\circ}\right)$ za područje Knina u razdoblju 1990.-2010.

Table 1. Monthly and annual average temperature of air $\left(\mathrm{C}^{\circ}\right)$ for the Knin area in the period 1990-2004.

\begin{tabular}{|c|c|c|c|c|c|c|c|c|c|c|c|c|c|}
\hline \multirow{2}{*}{$\begin{array}{c}\text { Godine } \\
\text { Years }\end{array}$} & \multicolumn{13}{|c|}{ M J E S E C I- MON THS } \\
\hline & $\mathbf{I}$ & II & III & IV & v & VI & VII & VIII & IX & $x$ & $\mathbf{X I}$ & XII & $\bar{x}$ \\
\hline 1990. & 3,7 & 8,3 & 11,3 & 11,2 & 16,4 & 20 & 23,2 & 23,1 & 17,2 & 14,7 & 9,2 & 4,1 & 13,5 \\
\hline 1991. & 4,1 & 3 & 10,8 & 10,3 & 12,8 & 20,2 & 23,6 & 23,1 & 19,6 & 12,1 & 8,8 & 2,6 & 12,6 \\
\hline 1992. & 3,5 & 5,3 & 8,5 & 12,3 & 18 & 19,2 & 22,8 & 25,2 & 19 & 14,4 & 10,2 & 4,1 & 13,5 \\
\hline 1993. & 3,4 & 3,9 & 6,2 & 12 & 18,2 & 21,3 & 22,9 & 24,9 & 17,9 & 14,7 & 5,4 & 6,6 & 13,1 \\
\hline 1994. & 5,7 & 4,8 & 11 & 12,1 & 17,6 & 20,8 & 25,3 & 24,9 & 19,6 & 12,6 & 10,4 & 5,2 & 14,2 \\
\hline 1995. & 3,7 & 8,1 & 7,1 & 10,8 & 15,7 & 18,6 & 24,1 & $* *$ & 16,3 & 14,4 & 7,1 & 5,2 & $* *$ \\
\hline 1996. & 4,6 & 2,8 & 5,8 & 12 & 16,9 & 20,9 & 22,6 & 22,1 & 14,4 & 12,8 & 9,8 & 3,9 & 12,4 \\
\hline 1997. & 5 & 6 & 9,7 & 7,9 & 16,4 & 21,2 & 22,1 & 21,4 & 18,7 & 11,3 & 9,2 & 6,2 & 12,9 \\
\hline 1998. & 5,7 & 8,2 & 6,9 & 11,9 & 16,5 & 21 & 24 & 24,2 & 17 & 13,4 & 6,2 & 2,3 & 13,1 \\
\hline 1999. & 4,3 & 2,7 & 8,9 & 12,3 & 17,3 & 20,9 & 23 & 23,2 & 19,1 & 13,9 & 7 & 5,1 & 13,2 \\
\hline 2000. & 1,6 & 5,6 & 7,5 & 13,7 & 18 & 22,1 & 22,5 & 24,9 & 18,3 & 15,1 & 11,4 & 7,1 & 14 \\
\hline 2001. & 6,3 & 6,2 & 11,3 & 11,1 & 18,5 & 19,7 & 23,9 & 24,8 & 15,5 & 15,1 & 7,2 & 1,7 & 13,4 \\
\hline 2002. & 2,4 & 7,3 & 10,9 & 11,6 & 17,3 & 22,4 & 23,2 & 21,2 & 16,6 & 13,3 & 11,8 & 5,2 & 13,6 \\
\hline 2003. & 3,2 & 1,5 & 8,2 & 11,6 & 19,5 & 24,5 & 24,6 & 26,9 & 17,6 & 11,7 & 11,2 & 5,7 & 13,8 \\
\hline 2004. & 2,5 & 4,6 & 7,6 & 11,9 & 14,4 & 20 & 23,2 & 22,3 & 18,8 & 15,3 & 8,8 & 5,8 & 12,9 \\
\hline 2005. & 2,4 & 1,4 & 6,9 & 11,7 & 17,2 & 21,3 & 23,3 & 20,2 & 18,3 & 13,4 & 8,1 & 4 & 12,3 \\
\hline 2006. & 2,8 & 4,1 & 6,4 & 12,6 & 16,4 & 20,8 & 24,7 & 20,4 & 19,2 & 15,5 & 8,6 & 6,2 & 13,1 \\
\hline 2007. & 6,9 & 8,3 & 10,1 & 14,7 & 18 & 21,6 & 24,3 & 23,1 & 16 & 12,4 & 7,1 & 3,5 & 13,8 \\
\hline 2008. & 6,2 & 6,1 & 8,6 & 12,4 & 17,9 & 21,1 & 23,6 & 24,2 & 17,4 & 14,4 & 9,6 & 6,2 & 14 \\
\hline 2009. & 3,1 & 4,7 & 8,3 & 13,6 & 18,9 & 19,8 & 23,5 & 24,7 & 20,4 & 12,9 & 9,1 & 5,7 & 13,7 \\
\hline 2010. & 3,2 & 5,2 & 7,7 & 12,9 & 16,2 & 20,9 & 24,4 & 22,7 & 17,6 & 11,9 & 10,8 & 4,6 & 13,2 \\
\hline
\end{tabular}

Izvor: DHMZ, Zagreb 2013. 
D. Dujmović i sur.: Ocjena proizvodnog prostora Knina za uzgoj masline

Veoma značajan klimatski element koji često puta ograničava uzgoj pojedinih voćnih vrsta jesu apsolutno najniže temperature koje su prikazane u tablici 2.

Tablica 2. Apsolutno najniže temperature zraka $\left(C^{\circ}\right)$ za područje Knina u razdoblju 1990.-2010.

Table 2. Absolutely the lowest air temperature $\left(\mathrm{C}^{\circ}\right)$ for the $\mathrm{Knin}$ area in the period 1990-2004.

\begin{tabular}{|c|c|c|c|c|c|c|c|c|c|c|c|c|c|}
\hline \multirow{2}{*}{$\begin{array}{l}\text { Godine } \\
\text { Years }\end{array}$} & \multicolumn{13}{|c|}{$M J E S E C I-M O N T H S$} \\
\hline & $\mathbf{I}$ & II & III & IV & v & VI & VII & VIII & IX & $x$ & $\mathbf{x I}$ & XII & 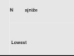 \\
\hline 1990. & $-9,8$ & $-5,3$ & $-2,3$ & 0,9 & 6,2 & 7,1 & 13,1 & 12,3 & 4,8 & 0,2 & $-3,4$ & -5 & $-9,8$ \\
\hline 1991. & $-7,6$ & $-11,6$ & 1,1 & $-0,3$ & 3,6 & 7,1 & 13,3 & 13,2 & 7,1 & -2 & $-3,9$ & $-7,9$ & $-11,6$ \\
\hline 1992. & $-6,4$ & $-8,1$ & -4 & 2 & 5,6 & 8,7 & 10,9 & 13,3 & 4,9 & 2,9 & $-1,9$ & $-8,5$ & $-8,5$ \\
\hline 1993. & $-8,5$ & $-6,6$ & -5 & 0,9 & 4,6 & 10 & 9,3 & 7 & 7 & 2,1 & -5 & $-4,4$ & $-8,5$ \\
\hline 1994. & -4 & $-6,9$ & $-1,5$ & 1,8 & 4 & 9,1 & 16,5 & 12,4 & 6,4 & $-0,8$ & $-0,3$ & $-6,7$ & $-6,9$ \\
\hline 1995. & $-7,6$ & $-4,8$ & $-3,8$ & $-2,5$ & 5,5 & 9,1 & 13,3 & $* * *$ & 6,2 & $-0,1$ & $-8,5$ & $-5,8$ & $* * *$ \\
\hline 1996. & $-6,1$ & $-7,7$ & $-8,5$ & $-0,5$ & 7,1 & 9,5 & 11,7 & 12,4 & 3,5 & -1 & $-3,3$ & $-10,4$ & $-10,4$ \\
\hline 1997. & $-6,3$ & $-7,4$ & $-1,2$ & $-3,1$ & 4,5 & 5,2 & 9,5 & 9,2 & 6,8 & $-0,4$ & $-6,1$ & $-4,1$ & $-7,4$ \\
\hline 1998. & $-8,7$ & $-4,7$ & $-4,4$ & 1,2 & 5 & 7,2 & 11,6 & 8,2 & 5,9 & 0,4 & $-4,8$ & -9 & -9 \\
\hline 1999. & $-6,3$ & -9 & $-1,7$ & 0,4 & 7,7 & 9 & 12,4 & 11,6 & 8,5 & 0,6 & $-4,9$ & $-10,1$ & $-10,1$ \\
\hline 2000. & $-13,5$ & $-6,4$ & $-5,7$ & 1,9 & 8,4 & 10,1 & 8,1 & 11 & 6,1 & $-0,3$ & $-1,7$ & $-9,1$ & $-13,5$ \\
\hline 2001. & $-3,8$ & $-5,2$ & 1,4 & 1,5 & 4,6 & 6,8 & 11,9 & 12,6 & 5,2 & 2 & $-3,8$ & $-8,8$ & $-8,8$ \\
\hline 2002. & $-9,5$ & $-4,4$ & 0,2 & 1,2 & 5,2 & 10,5 & 13,2 & 12,6 & 5,2 & 1,1 & $-2,4$ & -6 & $-9,5$ \\
\hline 2003. & $-9,5$ & $-8,5$ & $-4,5$ & $-4,1$ & 7,1 & 13 & 12,8 & 14,2 & 6,4 & $-2,1$ & $-0,4$ & $-5,3$ & $-9,5$ \\
\hline 2004. & $-8,4$ & $-5,6$ & $-4,6$ & 1,9 & 2,5 & 10,3 & 12 & 10,2 & 6,2 & 5,9 & $-7,1$ & $-6,3$ & $-8,4$ \\
\hline 2005. & $-9,2$ & $-10,3$ & $-0,6$ & 4,9 & 7,5 & 10,7 & 8,2 & 8,2 & 8,2 & $-0,7$ & $-4,1$ & $-7,2$ & $-10,7$ \\
\hline 2006. & $-10,6$ & $-6,6$ & $-4,5$ & 1 & 5,1 & 9,3 & 14,1 & 6,8 & 8,3 & $-0,8$ & $-2,5$ & $-7,7$ & $-10,6$ \\
\hline 2007. & $-5,1$ & $-2,2$ & 1,1 & 1,4 & 7,4 & 9,6 & 9,9 & 11,3 & 4,6 & $-0,8$ & $-4,4$ & $-6,6$ & $-6,6$ \\
\hline 2008. & $-8,4$ & $-8,3$ & $-2,4$ & 1,4 & 6,5 & 10,4 & 12,5 & 9,8 & 4 & 1,4 & $-4,8$ & $-8,4$ & $-8,4$ \\
\hline 2009. & $-9,1$ & $-4,9$ & $-1,7$ & 4,7 & 6,6 & 9,8 & 11,5 & 14 & 8 & $-1,9$ & $-2,9$ & $-14,3$ & $-14,3$ \\
\hline 2010. & $-9,4$ & -8 & $-3,6$ & 1,5 & 5,5 & 8,3 & 11,7 & 8,7 & 5 & $-1,7$ & $-1,1$ & $-10,5$ & $-10,5$ \\
\hline najniže & $-13,5$ & $-12,5$ & $-10,7$ & $-4,1$ & 2,3 & 4,8 & 8,1 & 6,8 & 3,5 & $-2,8$ & $-8,5$ & $-14,3$ & $-14,3$ \\
\hline
\end{tabular}

Izvor: DHMZ, Zagreb 2013.

Količina oborina je važan klimatološki parametar za ocjenu proizvodnog prostora. Podaci o prosječnim mjesečnim i godišnjim količinama oborina prikazani su u tablici 3. 
D. Dujmović i sur.: Ocjena proizvodnog prostora Knina za uzgoj masline

Tablica 3. Prosječne mjesečne i godišnje količine oborina $(\mathrm{mm})$ za područje Knina 1990.-2010.

Table 3. Monthly and annual average precipitation $(\mathrm{mm})$ for the Knin area 19902004.

\begin{tabular}{|c|c|c|c|c|c|c|c|c|c|c|c|c|c|}
\hline \multirow{2}{*}{$\begin{array}{l}\text { Godina } \\
\text { Years }\end{array}$} & \multicolumn{13}{|c|}{ M JESECI-MONTHS } \\
\hline & $\mathbf{I}$ & II & III & IV & v & VI & VII & VIII & IX & $x$ & $\mathrm{XI}$ & XII & $\begin{array}{c}\text { Ukupno } \\
\text { Total }\end{array}$ \\
\hline 1990. & 1,4 & 23,2 & 29,5 & 127,7 & 79,9 & 44,7 & 18,1 & 33,1 & 111,1 & 149,6 & 161,9 & 113,3 & 891,5 \\
\hline 1991. & 48,7 & 94,4 & 44,1 & 130,8 & 119,7 & 55,5 & 41,7 & 47,8 & 89,6 & 155,2 & 191,2 & 20,0 & $1.038,7$ \\
\hline 1992. & 18,2 & 2,7 & 122,3 & 42,9 & 54,1 & 109,4 & 99,8 & 54,5 & 21,3 & 238,3 & 134,3 & 49,6 & 968,4 \\
\hline 1993. & 1,4 & 0,5 & 60,0 & 84,8 & 34,2 & 50,8 & 21,4 & 25,4 & 137,8 & 184,8 & 242,0 & 161,5 & $1.004,6$ \\
\hline 1994. & 110,2 & 90,6 & 35,1 & 166,5 & 45,7 & 80,4 & 21,7 & 91,7 & 97,5 & 74,0 & 61,9 & 33,8 & 909,1 \\
\hline 1995. & 91,3 & 97,0 & 106,4 & 61,6 & 119,9 & 162,3 & 51,7 & $* * *$ & 113,0 & 11,7 & 83,9 & 141,0 & $* * *$ \\
\hline 1996. & 95,3 & 44,1 & 72,6 & 32,7 & 111,0 & 35,1 & 9,6 & 66,2 & 278,6 & 96,7 & 172,7 & 122,1 & $1.136,7$ \\
\hline 1997. & 54,9 & 54,7 & 17,5 & 93,5 & 104,1 & 57,1 & 55,8 & 74,2 & 50,6 & 60,7 & 151,5 & 150,7 & 925,3 \\
\hline 1998. & 53,9 & 5,4 & 16,5 & 14,6 & 52,8 & 98,4 & 24,1 & 31,9 & 221,5 & 148,8 & 67,5 & 60,8 & 931,2 \\
\hline 1999. & 87,9 & 94,0 & 44,7 & 141,5 & 127,8 & 48,6 & 64,3 & 75,7 & 81,2 & 64,8 & 152,5 & 150,7 & $1.133,7$ \\
\hline 2000 & 23,4 & 25,7 & 93,9 & 93,0 & 101,0 & 5,7 & 30,7 & 0,0 & 75,0 & 85,1 & 190,7 & 147,1 & 871,3 \\
\hline 2001. & 119,7 & 18,7 & 115,8 & 123,3 & 58,7 & 53,8 & 16,6 & 9,9 & 172,3 & 33,5 & 152,0 & 43,0 & 917,2 \\
\hline 2002. & 13,8 & 106,5 & 1,0 & 99,9 & 107,3 & 34,3 & 91,9 & 255,1 & 110,7 & 66,2 & 114,3 & 86,0 & $1.087,0$ \\
\hline 2003. & 184,2 & 16,2 & 5,6 & 29,4 & 30,9 & 123,0 & 14,8 & 16,0 & 79,9 & 181,0 & 126,5 & 36,9 & 844,4 \\
\hline 2004 & 140,0 & 179,0 & 129,7 & 214,0 & 92,5 & 99,3 & 8,0 & 27,4 & 50,9 & 87,2 & 118,0 & 200,6 & $1.346,6$ \\
\hline 2005. & 4,9 & 93,0 & 63,7 & 110,8 & 58,2 & 11,4 & 45,1 & 255,3 & 96,0 & 157,6 & 130,4 & 298,6 & $1.325,0$ \\
\hline 2006 & 116,8 & 83,8 & 86,3 & 91,1 & 68,2 & 28,4 & 30,5 & 172,9 & 40,9 & 13,7 & 56,3 & 33,9 & 822,8 \\
\hline 2007. & 59,0 & 137,9 & 130,0 & 14,4 & 96,6 & 102,2 & 30,2 & 157,2 & 97,2 & 57,6 & 59,9 & 66,7 & $1.009,0$ \\
\hline 2008. & 72,1 & 10,7 & 113,1 & 91,6 & 48,9 & 199,6 & 23,1 & 6,1 & 26,0 & 42,3 & 175,9 & 152,6 & 962,0 \\
\hline 2009. & 168,7 & 107,3 & 49,0 & 103,9 & 29,7 & 122,7 & 61,7 & 27,2 & 34,3 & 92,2 & 138,6 & 202,5 & $1.137,8$ \\
\hline \multirow[t]{2}{*}{2010} & 179,2 & 129,4 & 73,9 & 123,1 & 145,7 & 88,2 & 62,5 & 48,9 & 117,7 & 54,6 & 223,8 & 169,0 & $1.416,0$ \\
\hline & 78,3 & 67,5 & 67,2 & 94,8 & 80,3 & 76,7 & 39,2 & 73,8 & 100,1 & 97,9 & 138,4 & 116,2 & $1.033,9$ \\
\hline
\end{tabular}

Izvor: DHMZ, Zagreb 2013.

Metoda ocjena proizvodnog prostora za uzgoj masline

Za ocjenu proizvodnog prostora za uzgoj masline koristili smo metodu po Briccoliu (1925.), modificiranu za naše prilike po Miljkoviću (1984.). Kod ocjene prilika tla za uzgoj masline u razmatranje smo uzeli tip tla, dubinu profila, teksturni sastav i reakciju tla. Mogući broj bodova za teksturu tla prikazuje tablica 4. 
Tablica 4. Negativni broj bodova za uzgoj masline s obzirom na teksturu tla

Table 4. Negative number of points for olive cultivation with respect to texture of soil

\begin{tabular}{|c|c|}
\hline Tekstura tla / Soil texture & $\begin{array}{c}\text { negativnih bodova } \\
\text { negative points }\end{array}$ \\
\hline ilovasta pjeskulja / Silt loam & 4 \\
\hline pjeskovita ilovača / pervious sandy loam & 1 \\
\hline Ilovača / loam & 4 \\
\hline ilovasta glina / clay loam & 12 \\
\hline Glina / clay & 12 \\
\hline
\end{tabular}

Dubina tla je veoma važan element u ocjeni proizvodnog prostora za uzgoj trajnih kultura. Mogućnost prokorjenjivanja masline je u direktnoj vezi sa dubinom profila, a mogući broj negativnih bodova s obzirom na dubinu profila prikazuje tablica 5.

Tablica 5. Mogući broj negativnih bodova s obzirom na dubinu profila tla

Table 5. Possible number of negative points regarding the depth of the soil

\begin{tabular}{|c|c|}
\hline $\begin{array}{c}\text { Dubina profila }(\mathrm{cm}) \\
\text { Depth of soil }(\mathrm{cm})\end{array}$ & $\begin{array}{c}\text { negativnih bodova } \\
\text { negative points }\end{array}$ \\
\hline$<20$ & 40 \\
\hline $20-30$ & 30 \\
\hline $30-40$ & 15 \\
\hline $40-50$ & 10 \\
\hline $50-60$ & 5 \\
\hline $60-80$ & 2 \\
\hline $80-100$ & 1 \\
\hline $100-120$ & 1 \\
\hline $120-140$ & 1 \\
\hline $140-160$ & 0 \\
\hline$>160$ & 0 \\
\hline
\end{tabular}


Iako se maslina uspješno uzgaja na tlima slabo alkalne reakcije ipak za uzgoj joj najbolje odgovaraju blago kisela do neutralna tla. Ocjenu proizvodnog prostora s obzirom na reakciju tla prikauzje tablica 6.

Tablica 6. Mogući broj negativnih bodova za uzgoj masline s obzirom na reakciju tla.

Table 6. Possible number of negative points for olive growing in the respect to soil reaction.

\begin{tabular}{|c|c|}
\hline $\begin{array}{c}\mathrm{pH} \text { vrijednost } \\
\mathrm{pH} \text { reaction of soil }\end{array}$ & $\begin{array}{c}\text { negativnih bodova } \\
\text { negative points }\end{array}$ \\
\hline$<4$ & 5 \\
\hline $4,0-5,0$ & 3 \\
\hline $5,0-6,0$ & 1 \\
\hline $6,0-6,5$ & 1 \\
\hline $6,5-7,0$ & 1 \\
\hline $7,0-7,5$ & 1 \\
\hline $7,5-8,0$ & 1 \\
\hline $8,0-8,5$ & 1 \\
\hline $8,5-9,0$ & 10 \\
\hline$>9$ & 40 \\
\hline
\end{tabular}

Kod klimatskih elemenata u ocjenu proizvodnog prostora obavili smo na osnovu zahtjeva masline u pojedinim razdobljima razvoja (Miljković, 1974.). U tablici 7 prikazujemo vrijednosti oborina i temperatura u pojedinim razdobljima razvoja masline koje mogu biti ekscesivne, optimalne i nedovoljne za uzgoj masline (Briccoli, 1925.). Prema istom autoru razdoblja u godišnjem ciklusu masline su I razdoblje veljače, ožujka i travnja, II razdoblje svibanj i lipanj, III razdoblje srpanj i kolovoz, IV razdoblje rujan i listopad i V razdoblje studeni, prosinac i siječanj. 
Tablica 7. Ekscesivne, optimalne i nedovoljne količine oborina (mm) i temperature $\left({ }^{\circ} \mathrm{C}\right)$ za uzgoj masline u pojedinim razdobljima razvoja

Table 7. Excessive, optimal and insufficient amount of precipitation $(\mathrm{mm})$ and temperature $\left({ }^{\circ} \mathrm{C}\right)$ for olive growing in certain periods of olive development

\begin{tabular}{|l|l|c|c|c|c|c|}
\hline & & \multicolumn{5}{|c|}{ godišnja razdoblja razvoja } \\
& & \multicolumn{5}{|c|}{ annual development periods } \\
\hline & $\begin{array}{l}\text { Ekscesivne } \\
\text { Excessive }\end{array}$ & - & 35 & 120 & 130 & - \\
\hline oborine (mm) & $\begin{array}{l}\text { Optimalne } \\
\text { Optimal }\end{array}$ & $90-120$ & $19-24$ & $50-70$ & $70-90$ & - \\
\hline precipitation (mm) & $\begin{array}{l}\text { Nedovoljne } \\
\text { Insufficient }\end{array}$ & 60 & 15 & 38 & $30-50$ & - \\
\hline & $\begin{array}{l}\text { Ekscesivne } \\
\text { Excessive }\end{array}$ & - & 32 & 36 & - & - \\
\hline $\begin{array}{l}\text { temperature }\left({ }^{\circ} \mathrm{C}\right) \\
\text { temperature }\left({ }^{\circ} \mathrm{C}\right)\end{array}$ & $\begin{array}{l}\text { Nedovoljne } \\
\text { Insufficinet }\end{array}$ & -5 & 15 & 20 & 15 & 5 \\
\hline & & 10 & & & & \\
\hline
\end{tabular}

Prema Miljkoviću (1974.) i (1984.) kod bonitiranja zemljišta za maslinu za ocjene klime predloženo je najviše 60 bodova, a najveći mogući broj bodova u pojedinom godišnjem razdoblju prikazan je u tablici 8 .

Tablica 8. Najveći mogući broj bodova za ocjenu klime masline u pojedinim godišnjim razdobljima

Table 8. The highest possible points for assessment of olive climate in certain annual periods.

\begin{tabular}{|l|c|}
\hline \multicolumn{1}{|c|}{ Razdoblje / Period } & najviše bodova / maximal pioints \\
\hline I (veljača - travanj) / (february - april) & 17 \\
\hline II (svibanj - lipanj) / (may - june) & 15 \\
\hline III (srpanj - kolovoz) / (july - august) & 12 \\
\hline IV (rujan-listopad) / (september-october) & 8 \\
\hline V (studeni-siječanj) / (november-january) & 8 \\
\hline
\end{tabular}

Tijekom godišnjeg razvojnog ciklusa masline razlikuju se pojedine fenofaze razvoja. Tijekom pojedinih fenofaza u maslini se odvijaju i određeni fiziološki 
procesi. Kako bi se ovi procesi nesmetano odvijali potrebne su i najniže dnevne temperature pri kojima počinju pojedine fenofaze masline, a njihove vrijednosti prikazuje tablice 9 .

Tablica 9. Najniže dnevne temperature potrebne za početak pojedine fenofaze masline prema Caruso (1883.).

Table 9. The lowest daily temperatures required for the beginning of each olive phenophase according to Caruso (1883.).

\begin{tabular}{|l|c|}
\hline \multicolumn{1}{|c|}{ Fenofaza / phenophase } & $\begin{array}{c}\text { najniža temperatura }\left({ }^{\circ} \mathrm{C}\right) \\
\text { / the lowest temperature }\left({ }^{\circ} \mathrm{C}\right)\end{array}$ \\
\hline početak pupanja / the start budding & $10,5-11$ \\
\hline pojava cvjetnih grozdića / start of the flower cluster & 15 \\
\hline Cvatnja / blooming & $18-19$ \\
\hline oplodnja i zametanje ploda / fertilization and anthesis & $21-22$ \\
\hline zrioba ploda / maturity & $21-22$ \\
\hline
\end{tabular}

Niske zimske temperature su najčešći ograničavajući čimbenik uzgoja masline. Učestalost pojave niskih temperatura koje mogu uzrokovati štete na masline se boduje $\mathrm{u}$ negativnim postotnim bodovima $\mathrm{s}$ obzirom na stupanj oštećanja stabla (Miljković, 1984.). Kod ove ocjene važno je napomenuti kako se pri niskim zimskim temperaturama nižim od $-12^{\circ} \mathrm{C}$ dolazi do oštećenja masline četvrtog i petog stupnja i ako se ova temperatura javlja jednom u dvadeset godina područje može dobiti 20 odnosno 30 negativnih bodova $\mathrm{s}$ obzirom na stupanj oštećenja masline.

Isto tako negativnim bodovima se boduje i učestalost pojave olujnih vjetrova i pojave kiše u doba cvatnje masline. Kod ovog bodovanja moguće je ostvariti po 2-3 negativna boda ako se olujni vjetrovi ili kiše javljaju tri puta tijekom desetogodišnjeg razdoblja.

Zbirno promatrano, a prema Miljkoviću (1984.) za ocjenu proizvodnog područja za uzgoj masline reralno je predvidjeti 60 bodova za ocjenu klime i 40 bodova za ocjenu pedoloških prilika područja. 


\section{REZULTATI RADA}

Ocjena pedoloških prilika

Prema predstavljenoj metodi bonitiranja područje grada Knina s obzirom na teksturu tla može dobiti četiri negativna boda odnosno 12 negativnih bodova s obzirom da su u području zastupljena ilovasta tla ili ilovasto glinovita tla.

$S$ obzirom da je dubina profila u predmetnom području veća od $150 \mathrm{~cm}$ ovo područje se može ocijeniti kao besprijekorno bez negativnih bodova. S jednim negativnim bodom ovo područje se može ocijeniti zbog reakcije tla koja se kreće od pH 7.1 do pH 8.3 u području Knina.

Zbir negativnih bodova za ocjenu pedoloških prilika za uzgoj masline u području Knina prikazuje tablica 10.

Tablica 10. Ukupan zbroj negativnih bodova za ocjenu pedoloških prilika Knina za uzgoj masline

Table 10. The summe of negative points for evaluation of pedological conditions for olive growing in Knin area.

\begin{tabular}{|l|c|}
\hline \multicolumn{1}{|c|}{ Kategorija / Category } & $\begin{array}{c}\text { broj negativnih bodova } \\
\text { / number of negative points }\end{array}$ \\
\hline ilovasta tla / loam soil & 4 \\
\hline dubina $(>150 \mathrm{~cm}) /$ depth $(>150 \mathrm{~cm})$ & 0 \\
\hline $\mathrm{pH} 7.1-8.3$ & $\mathbf{5}$ \\
\hline Ukupno / Total & \\
\hline & 12 \\
\hline glinovito-ilovasta / clay loam soil & 0 \\
\hline dubina $(>150 \mathrm{~cm}) /$ depth $(>150 \mathrm{~cm})$ & 1 \\
\hline pH $7.1-8.3$ & $\mathbf{1 3}$ \\
\hline Ukupno / Total & \\
\hline
\end{tabular}

U dijelovima područja gdje prevladava ilovasto tlo ukupno se može dobiti pet negativnih bodova od mogućih 40 dok se u dijelovima područja gdje prevladavaju glinovito ilovasta tla može dobiti najviše 13 negativnih bodova.

Ocjena klimatskih prilika

Zbog uočenih nedostataka ocjene proizvodnog prostora za uzgoj masline prema Bricolli (1925.), Miljković (1984.) je prema našim ekološkim uvjetima 
za uzgoj masline, na temelju klimatskih podataka iz razdoblja od 1948. do 1960. godine razradio vlastitu metodu za bonitiranje klime za maslinu. Prema ovoj metodi pojedina razdoblja se dijele u podrazdoblja, ocjenu proizvodnog prostora Knina po ovoj modificiranoj metodi prikazuje tablica 11.

Tablica 11. Ocjena proizvodnog prostora područja Knina s obzirom na klimatske elemente

Table 11. Evaluation of climate conditions for olive growing in Knin area.

\begin{tabular}{|c|c|c|c|}
\hline $\begin{array}{c}\text { Razdoblje } \\
\text { Period }\end{array}$ & $\begin{array}{c}\text { Godišnje doba } \\
\text { Seasons }\end{array}$ & $\begin{array}{c}\text { Podrazdoblje } \\
\text { Sub period }\end{array}$ & $\begin{array}{c}\text { Ukupno bodova } \\
\text { Total points }\end{array}$ \\
\hline I & $\begin{array}{c}\text { veljača - travanj } \\
\text { february-april }\end{array}$ & IV & 7 \\
\hline II & $\begin{array}{c}\text { svibanj i lipanj } \\
\text { may and june }\end{array}$ & I/II & 13,5 \\
\hline III & $\begin{array}{c}\text { srpanj i kolovoz } \\
\text { july and august }\end{array}$ & I & 6 \\
\hline IV & $\begin{array}{c}\text { rujan i listopad } \\
\text { september and october }\end{array}$ & III & 0 \\
\hline V & studeni - siječanj & & $\mathbf{4 0 , 5}$ \\
\hline november - january & & & 6 \\
\hline Thupno bodova points & & &
\end{tabular}

Od ukupno 60 bodova za ocjenu klimatskih prilika nekog područja za uzgoj masline područje grada Knina može dobiti 40.5 bodova. Prema ovako analiziranim klimatskim čimbenicima može se samo općenito ocijeniti prikladnost određenog područja za uzgoj masline.

Pozeba može izazvati velike štete na maslinama, ovisno o mnogim čimbenicima. Kod procjenjivanja opasnosti od niskih temperatura potrebno je ustanoviti karakter ozljeda, kao i učestalost pojavljivanja pozebe. Ocjenu proizvodnog prostora grada Knina s obzirom na učestalost pozebe prikazuje tablica 12. 
Tablica 12. Ocjena proizvodnog prostora okolice grada Knina za uzgoj masline s obzirom na učestalost ekscesivnih temperatura.

Table 12. Evaluation for olive growing in Knin area due to frequency of excessive temperatures.

\begin{tabular}{|c|c|c|c|}
\hline $\begin{array}{l}\text { Stupanj oštećenja } \\
\text { Degree of demage } \\
\text { (kritačna temp.) } \\
\text { (critical temp.) }\end{array}$ & $\begin{array}{c}\text { Opis oštećenja } \\
\text { Description of demage }\end{array}$ & $\begin{array}{c}\text { Učestalost pojave u } \\
\text { dvadesetogodišnjem } \\
\text { razdoblju } \\
\text { Frequency of } \\
\text { occurrence on the } \\
\text { twenty-year period }\end{array}$ & $\begin{array}{l}\text { Negativnih } \\
\text { bodova } \\
\text { Negative } \\
\text { points }\end{array}$ \\
\hline $\begin{array}{l}\left.\text { I (niže od }-8^{\circ} \mathrm{C}\right) \\
\mathrm{I}\left(\text { lower than }-8^{\circ} \mathrm{C}\right)\end{array}$ & $\begin{array}{l}\text { povrede kore grana i } \\
\text { jednogodišnjih izboja } \\
\text { bark branchs and one year } \\
\text { shoots breaches }\end{array}$ & 5 & 4 \\
\hline $\begin{array}{l}\text { II (niže od }-9^{\circ} \mathrm{C} \text { ) } \\
\text { II (lower than }-9^{\circ} \mathrm{C} \text { ) }\end{array}$ & $\begin{array}{l}\text { slabe povrede } \\
\text { jednogodišnjih grana } \\
\text { minor breaches of the one } \\
\text { year shoot }\end{array}$ & 4 & 8 \\
\hline $\begin{array}{l}\text { III (niže od }-10^{\circ} \mathrm{C} \text { ) } \\
\text { III (lower than }-10^{\circ} \mathrm{C} \text { ) }\end{array}$ & $\begin{array}{l}\text { slabije povrede koje } \\
\text { ograničavaju rast stabla } \\
\text { minor breaches of the bark } \\
\text { which limited of vigor }\end{array}$ & 6 & 15 \\
\hline $\begin{array}{l}\left.\text { IV (niže od }-12^{\circ} \mathrm{C}\right) \\
\text { IV (lower than }-12^{\circ} \mathrm{C} \text { ) }\end{array}$ & $\begin{array}{l}\text { jače povrede krošnje } \\
\text { i debla } \\
\text { stronger injuries of the } \\
\text { trunk and canopy }\end{array}$ & 1 & 10 \\
\hline $\begin{array}{l}\mathrm{V}\left(\text { niže od }-14^{\circ} \mathrm{C}\right) \\
\mathrm{V}\left(\text { lower than }-14^{\circ} \mathrm{C}\right)\end{array}$ & $\begin{array}{l}\text { vrlo jake povrede } \\
\text { nadzemnog dijela } \\
\text { very strong injuries } \\
\text { of the tree }\end{array}$ & 1 & 15 \\
\hline & $\begin{array}{l}\text { Ukupno za područje Knina } \\
\text { Total of the Knin area }\end{array}$ & & 52 \\
\hline
\end{tabular}

Od mogućih 60 bodova za odnos temperature i oborina Knin ima 40,5. Kada se oduzmu negativni bodovi dobiveni samo za ekscesivne temperature u dvadesetogodišnjem razdoblju dobije se -11.5 negativnih bodova. Radi ove činjenice područje Knin se svstava u područja koja su neprihvatljiva za uzgoj masline. 
S obzirom na provedenu analizu možemo zaključiti kako bi u području Knina maslina mogla uspijevati s obzirom na pedološke prilike jer ovo područje ostvaruje ukupno od 27 do 35 bonitetnih poena u zavisnosti od tipa tla.

Analizom klime došli smo do zaključka kako su učestale niske zimske temperature najveći ograničavajući čimbenik uzgoja masline u ovom području. Naime, temperature zraka niže od $-8^{\circ} \mathrm{C}$ mogu kod masline izazvati oštećenja prvog stupnja, a u ovom području se javljaju pet puta tijekom dvadesetogodišnjeg. Isto tako niske zimske temperature koje izazivaju oštećenja masline većeg stupnja (II-V) javljaju se redovito u ovom području.

\section{LITERATURA}

BAŠIĆ, F., BOGUNOVIĆ, M., HUSNJAK, S., KISIĆ, I., MESIĆ, M., MIROŠEVIĆ, N., ROMIĆ, D., JURIĆ, I., ŽUGEC, I., BOŽIĆ, M. (2004.): Regionalizacija Hrvatske poljoprivrede. Agronomski fakultet Zagreb, Poljoprivredni fakultet Osijek i Ministarstvo poljoprivrede RH, Zagreb.

BRICCOLI, M. (1925.): Il clima dell olivo in Italia. Nuovi Annali d Agr. 3-4:

CARUSO, G. (1883.): Monografia dell Olivo. Unione Tipografico-Rditrice Torino pp 35.

DRŽAVNI HODROMETEOROLOŠKI ZAVOD (2014.): Klimatski podaci za meteorološku postaju Knin.

GUGIĆ, J., STRIKIĆ, F., PERICA, S., ČMELIK, Z., JUKIĆ, LJ. (2007.): Proizvodnja sadnog materijala masline u Republici Hrvatskoj. Pomologia Croatica 13, (4): 229-250.

INTERNATIONAL OLIVE COUNCIL, MADRID (2016.): $7^{\text {th }}$ meeting of the statistics working group, Madrid, 3 Octobre 2016.

JURAS, I. (1957.): Tla Kninskog područja. Institut za jadranske kulture Split.

MICHELI VITTURI R. A. (1788.): Sull` Introduzione degli Ulivi nei Territotj mediterranei dell Dalmazia, e sulla loro coltivazione. Nella Stamperia Coleti, Venezia.

MILJKOVIĆ, I. (1974.): Prednacrt jedinstvene metode bonitiranja zemljišta za uzgoj masline. Poljoprivredni fakultet u Zagrebu

MILJKOVIĆ, I. (1984.): Bonitiranje zemljišta kulture voćnjaka. Agronomski glasnik 46, (6): 881-919. 
PERIČIĆ, Š . (1998/99.): Prilog poznavanju gospodarstva kninskog kraja u 19. Stoljeću. Acta historico-oeconomica. 25-26: 64-94.

SOLDO, J. A. (2005.): Grimanijev zakon. Zagreb: FF Press - Zavod za hrvatsku povijest Filozovskog fakulteta Sveučilišta u Zagrebu.

STRIKIĆ, F., GUGIĆ, J., KLEPO, T. (2012.): Stanje Hrvatskog maslinarstva. Glasilo biljne zaštite 12, (4): 271-276.

\section{Adresa autora - Author's address:}

Dimitrije Dujmović,

Marko Šuste,

Marko Duvančić,

Veleučilište "Marko Marulić", Knin

Petra Krešimira IV br. 30, Knin, Hrvatska

Frane Strikić, e-mail: frane@krs.hr

Institut za jadranske kulture i melioraciju krša Split,

Put Duilova 11, 21000 Split, Hrvatska;

Znanstveni centar izvrsnosti za bioraznolikost i molekularno oplemenjivanje bilja, Zagreb, Svetošimunska 25, Zagreb, Hrvatska 
